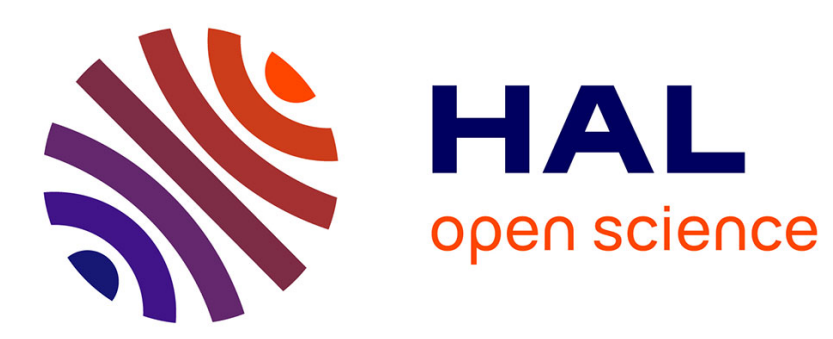

\title{
Social Representations of Physical Disability in a Professional Environment
}

Bernardeau-Moreau Denis

\section{To cite this version:}

Bernardeau-Moreau Denis. Social Representations of Physical Disability in a Professional Environment. Journal of Applied Social Science, 2021, 15, pp.66 - 79. 10.1177/1936724420982964 . hal03270484

\section{HAL Id: hal-03270484 \\ https://hal.science/hal-03270484}

Submitted on 24 Jun 2021

HAL is a multi-disciplinary open access archive for the deposit and dissemination of scientific research documents, whether they are published or not. The documents may come from teaching and research institutions in France or abroad, or from public or private research centers.
L'archive ouverte pluridisciplinaire HAL, est destinée au dépôt et à la diffusion de documents scientifiques de niveau recherche, publiés ou non, émanant des établissements d'enseignement et de recherche français ou étrangers, des laboratoires publics ou privés. 


\title{
Social Representations of Physical Disability in a Professional Environment
}

\author{
$\underline{\text { Bernardeau-Moreau Denis }}$
}

First Published January 19, 2021 Research Article https://doi.org/10.1177/1936724420982964

Article information

\section{?}

\section{Abstract}

Our article addresses disability as a social construct. More precisely, our intention is to see to what degree practices and exchange and interaction situations operate on social representations of physical disability in professional environments. Our aim is to provide some elements for reflection with regard to the imagined issues of physical disability in the workplace by focusing, in particular, on the social representations that they trigger among employees and managers who work with disabled colleagues on a day-to-day basis.

Keywords disabled employees, social representations, energy company, perception of physical disability, social interactions, internal communications

Our paper focuses on the social construction of disability (Abberley 1987; Conrad and Barker 2010). Exclusion, as De Foucault and Piveteau (1995:33) write, is a person being unable to contribute to the common good. It can be due to the disability itself or also and more importantly by the social aspect that disability carries. In this sense, social representations play a vital role in the social construction of disability. As Compte (2008:117) notes, they are at the heart of this construction as the translation of complex real and imagined relationships, objective and symbolic with regard to disability. By questioning disability, we are also questioning difference and acceptance, the real or imagined gap by social norms. Our intention is to analyze the development of representations of disability during social interaction situations, those that, in our opinion, form one of the key concerns stifling or facilitating professional integration of this particular audience. Through these interaction games susceptible to developing prejudices and preconceived ideas, we also wish to investigate the role that public authorities and business can have in facilitating professional integration for disabled people.

For many authors (Barel \& Fremeaux 2012; Blanc 2006; Gardou 1991; Kerroumi 2007; Le Dantec 2004), the integration of disabled people in the workplace continues to be insufficient in our society. Although various studies indicate that there has been noticeable progress, the 
2014 study by AGEFIPH and FIPHFP ${ }^{1}$ highlights that only two-thirds of physically disabled persons who are capable of working were currently in employment (AGEFIPH's activity report [2013] establishes that in 2005, of the 938,820 disabled people who are able to work, 680,000 were actually in work and 570,000 of this number were employed in an ordinary working environment). The Le Houerou (2014) parliamentary report states that the rate of unemployment among disabled people was 22 percent, which is double the national average. Despite incentives from public bodies, AGEFIPH and FIPHFP note that companies and these public bodies are still having difficulties with integrating disabled people into their teams. In a statement dated February 29, 2012 (information report $n^{\circ} 635$ of the Senate of 2011-2012, by Ms. Claire-Lise Campion and Ms. Isabelle Debré) addressed to the minister for the budget, solidarity and the civil service, the Cour des Comptes (the French national body for auditing public funds) even indicated that there is "a serious inequality in salary" with regard to the inclusion of disabled people in the workplace. This inequality between disabled and nondisabled people concerns both the private and public sectors. In spite of the 1987 and 2005 laws (law $\mathrm{n}^{\circ} 87-517$ of July 10, 1987, in support of employing disabled persons, law $\mathrm{n}^{\circ} 2005$ 102 of February 11, 2005, for equal rights and opportunities, involvement, and civic rights for disabled persons), that impose a financial penalty on employers with at least 20 employees that do not achieve the six percent quota of disabled workers, the share of disabled people in public and private companies is still low. Of the 100,000 private-sector establishments affected by this employment obligation in 2011 (2014 key figures from AGEFIPH and FIPHFP, p. 2 and 3), only 41 percent of them meet or exceed the required threshold. Other establishments either have agreements with service providers regarding indirect employment (11 percent; +2 points compared with the previous year) or prefer to pay their contributions to AGEFIPH (47 percent; -2 points; for 2013, the total sum of penalties increased to $€ 441$ million). The report fares little better in the public sector. Of the 10,500 establishments listed, only 51 percent meet or exceed the required six percent. Furthermore, on a national level, AGEFIPH and FIPHFP (Le Houerou 2014) report that in 2013, the percentage of disabled people recruited into direct employment increased to 3.1 percent in the private sector and to 4.64 percent in the public sector (3.56 percent in government civil service, 5.20 percent in hospital public service and 5.66 percent in regional civil service). However, despite clear legislation, it appears that many companies still prefer to pay the fine rather than employ disabled people. Although figures are certainly improving, there is still a persistent gap.

Researchers have questioned the causes of this report. In the 1990s, Barnes, Mercer, and Shakespeare (1999) explain that disability is part of a "social model." For these authors, disabling barriers are the product, not of an individual phenomenon, but of the social world in which people with disabilities live. There are multiple causes stemming from economics, culture, sociology, and facilities. For (Davin et al. 2006) social inequalities facing disabled people are the result, in part, of inadequate facilities and insufficient financial means. It is the difficulties of adapting jobs and the costs of altering access to buildings and offices that make employers hesitate. According to a 2014 AGEFIPH study, it appears that only one in five disabled people benefit from a modification to their working hours or alleviated tasks. The 1999 HID study (Mormiche and Goillot 2003) also highlights that disabled people have a level of education that is too inadequate for jobs. The Le Houerou (2014) report states that 78 percent of disabled persons have a level of education that is equal to or lower than BEP (College Certificate) ou CAP (Certificate of Professional Competence)-INSEE reports that on a national scale, this rate is 50.4 percent. Auerbacher (2007) notes that disabled people do not receive proper training, and even less training, throughout their lives. For Kerroumi (2007), the difficulty is in conducting more research into social representations and the extent that companies still too often consider disability as a factor in unproductivity. This author 
continues that despite efforts by organizations and public bodies, disability is still associated with negative collective associations, including social issues that are imagined to be disruptive to a company's good operation (Kerroumi 2007). Point, Fontaine, and Berthélemé (2010) also observe that disability is rarely presented as an asset for companies, and because of this, employers remain reluctant to hire disabled employees.

The social concept of representation was established by Durkheim (as Ferreol [1991:244] recollects, Durkheim was the first to give the concept of representation a status in sociology) and makes a distinction between collective representations and individual representations. Moscovici (2003:81) went on to specify that the former have the particular feature of being a substrate of society as a whole. They form categories of thought that interpret society as a sui generis reality, in that they have a certain stability that individual representations do not, as these are more varied due to being created in the consciousness of each person (Moscovici 2003). Weber (1971:12) is of the opinion that representations, regardless of their categories, are social above all because they form frames of reference and schools of thought that guide and direct people's actions on both individual and collective levels. Moscovici agrees with this point of view. He believes that "what makes it possible to consider representations as being social is less the individual or group supports and more the fact that they are developed over the course of exchanges and interactions" (1982:99). What are the representations of disability in the workplace? Do these change through contact with disabled employees? What role does public policy change has to play? What role can the company play to encourage integration of workers with disabilities?

For that, we have opted for a multi-methodology approach (Abric 1994). The department in which we carried out our survey from 2014 to 2016 belongs to a subsidiary of an energy company employing several thousand people spread throughout the country. The disabled workers we met had either a motor disability characterized by a limited ability to move, a visual or auditory sensory disability, or finally a disabling disease, mainly respiratory or autoimmune. To identify work situations mixing disabled and nondisabled workers, we carried out exploratory interviews, which Abric (1994:75) states are a "major tool in discovering representations." In doing this, we conducted a series of exploratory interviews with social and medical managers responsible for matters regarding disability in France. We also interviewed some disabled employees. Our goal was to gather stories of life and experience. In total, 22 interviews were held (Appendix A), enabling us to better contextualize our subject and to choose the interaction situations to be analyzed. We then constituted a sample of employees based on the exploratory interviews and the possibilities of access to the field. Thirty employee volunteers were selected with the agreement of their company (Appendix B). We then used De Rosa's (2003) method of the free association. Our objective was to identify the elements that make up employees' representations (central core) based on the key term "disability in the workplace." For this, we created two groups differentiated according to whether the employees were or were not in direct and regular contact with workers with disabilities. This stage enabled us to identify the recurrent words and expressions used in discussions (frequency, meaning, classification). By combining the various methods (interviews, free association), we were able to have a more precise identification of the elements constituting the central core of those with disabilities are viewed at work in an energy company.

Our paper consists of four parts. In the first part, we shall set out the legal framework and its incentive role. In the second part, we shall show that improvements in how disability is viewed are tangible but slow. In the third part, we shall emphasize the social construction of 
disability and the evolution in the representations in social interaction situations. Finally, in the fourth part, we shall underline the importance for organizations to encourage internal dialogue capable of mitigating the impact of negative attitudes.

\section{A Legislative Framework That Encourages Organizations to Employ People with Disabilities}

As shown in Camberlein's (2011) works, the word "disability" (handicap in French) has only existed in France for a century. It spread gradually in the 1950s to 1960s to refer to those with a physical or mental disability or impairment. Its semantic use was only formalized in 1975 by the framework law for disabled people (law n $75-534$ of June 30,1975). The terms "disability" and "disabled people" (personnes handicapées or personnes en situation de handicap) have gradually come to replace other somewhat pejorative terms, such as "cripple" (infirmes), "handicapped" (invalides), or "misfits" (inadaptés). In 1987, a law for the employment of disabled persons (law n ${ }^{\circ} 87-517$ of July 10, 1987, in support of employing disabled persons) established the obligation for companies with more than 20 employees, whether full or part-time, to have disabled people make up at least six percent of their workforce. In 2005, France decided to modernize its legislation and promulgated the law of February 11, 2005 (law n²005-102 for equal rights and opportunities, involvement and civic rights for disabled persons) that defines disability in all its diversity. Article 2 in particular states that

a disability, as defined by this law, constitutes all limitation of activity or limited participation in society endured by a person due to a substantial, long-term or permanent deterioration in one or several physical, sensory, intellectual, cognitive or mental functions, multiple disabilities or an invalidating health problem.

Thanks to this law, disability is much more widely recognized in society. For Maryse Aïo (this interview and the following interviews were conducted in 2014), the national head of the disability mission in the agricultural social cooperative (mutuelle sociale agricole), the employment obligation created by the 2005 law grants disabled people a status and, above all, rights. For Nicolas Janda, head of training at the TH Conseil organization (the TH Conseil is an organization that provides consultancy, training and recruitment, specializing in managing diversity for organizations, particularly the employment of disabled persons), "this judicial document offers disabled people a better opportunity to find a job or to be integrated into the workplace." Works by Barbusse (2002, 2009), Blanc (2006), and Morin (2006) show that among disabled people, employment provides meaning and a feeling of usefulness. It is a place of activity and for creating social connections. Morin (2006:66) also remarks that work is a "health provider" as it encourages access to everything. For disabled people, integration in the workplace is therefore essential, even lifesaving. In addition, Blanc (2006:49) notes that it is "a test that is indicative of existing solidarity within democratic societies that are now ruined by globalisation."

\section{Changing Perceptions of Disability: Progress Certainly, But Slow}

So, although the law contributes to promoting the professional integration of disabled persons, what is the reality? Has the French population's perspective of disability changed with time? 
According to Alain Picciotto, head of the disability unit at the RATP public transport provider, "successive laws have made it possible to change viewpoints regarding disability and have also obliged companies to organize operations on the subject with objectives and results to achieve." A study conducted by IFOP in 2009 ("perceptions, views and experiences of employees concerning disability in the workplace," study carried out for ADIA and EURO RSCG C\&O) showed that 88 percent of those questioned think that it is easy to work alongside a disabled person. Sixty-two percent are of the opinion that a disabled person carries out his/her work just as well as any other employee. A study conducted by IFOP for AGEFIPH in November 2012 (survey for 25 years of AGEFIPH on employment and disabled people: crossed views of company managers and employees) highlighted that 85 percent of people questioned felt that conditions for disabled people have improved in France. Fiftyeight percent think that views of disability have changed positively over the last three years. A study conducted in 2014 by Higher Audiovisual Council (CSA study for CED "Disability in the workplace: perceptions in the French population") reported that more than four out of five people claimed to be comfortable with the idea of working alongside a physically disabled colleague. This same study specifies that 94 percent of French people surveyed thought that it is absolutely possible for someone with a physical disability to carry out a professional activity. In addition, two-thirds of French people believe that a disabled person is no less productive than someone who is not. Sixty-eight percent of respondents think it is normal and fair that there is a recruitment quota imposed on employers. A 2015 study (Guichet and Kaczmarek 2016) confirms this positive evolution of the representation of disability in companies. The results thus underline the very positive feedback from employers on their employees with disabilities. Ninety-eight percent of company managers thus declare that this has improved the perception of disability by other employees. The integration of people with disabilities transforms representations with a "snowball effect." As emphasized by Monique Pelletier, former minister and president of the French National Council for Disability (Conseil national handicap): "wheelchairs and white sticks are no longer frightening." " For the people we spoke to, the results of studies are encouraging because they show an positive regard in how disability is viewed in society. During our interview, Marie-Françoise Arrighi, head of the disability and integration project at Disney, confirmed the gradual awareness among French people, although she regrets that France is still lagging behind compared to the United Kingdom, Germany, and Switzerland. Claude Payrard, inter-regional disability representative for the Île-de-France region, recognizes that mentalities are changing and developing, and prejudices are fading, although he regrets that this development is still too slow. Alain Sauton, head of career support in the social ministries, states that

the law is a good thing, but there is a need to change views of disability in France. We have put in place marketing campaigns over several years, like awareness days and symposiums. Things are starting to develop and change. Furthermore, we now look at the skills of disabled employees. This is very important.

Therefore, it can be seen that all of these studies and testimonies show a positive change in the perception of disability. However, this trend is not necessarily followed by an actual integration of disabled people in the workplace. The IFOP 2012 study (cited previously) also reports that 57 percent of disabled people questioned believe that the 2005 law has changed nothing about their day-to-day lives. In addition, this survey highlights that 64 percent of this group thinks that integrating disabled workers into companies continues to be too difficult. For the majority of people we spoke to, effecting a deep change in society's view of disability remains a priority and a prerequisite. The matter of disability in the workplace is, of course, 
complex and involves all of the actors concerned fully: the national government, social partners, associations and also employers and employees.

\section{The Role of Interaction in Improving How Society Views Disability}

For Abric (2005), societal views and practices are inextricably linked and feed off each other: "views guide and determine the practices and the latter act by creating or transforming the views" (Abric:12). To verify that, we immersed ourselves in an energy company. The department in question, situated in the Paris area, employs 300 people, 18 of whom live with handicaps (representing 5.8 percent of the total payroll). According to the Labor Code (art. L5213-1), a disabled worker is any person whose possibilities of obtaining or keeping a job are effectively reduced as a result of the impairment of one or more physical, sensory, mental, or psychological functions (the International Classification of Functioning, Disability and Health [ICF] distinguishes five types of disabilities: motor, sensory, mental, psychic, and disabling). The disabled workers we met are technicians, maintenance engineers, construction site vehicle drivers, survey leaders, and so on. Their disabilities, both visible and invisible, are quite diverse - these include varying degrees of restricted mobility, various debilitating diseases (Parkinson's disease, diabetes, leukemia, Crohn's disease) and sometimes require specific equipment (bags, hearing aids or catheters). Most of the desks are placed in large open-plan areas with furnishings more or less adapted to the nature of the disability.

Having identified the employees working daily with or close by the members of staff with disabilities, we selected 30 of them. We then split them into two differentiated groups: Group A was comprised of 20 employees who worked with a colleague with a disability only occasionally and often indirectly. These were employees who, in carrying out their duties, discussed, or collaborated with their disabled colleagues from time to time, and only briefly. Contact is irregular and depends on the department's requirements. Group B, however, was comprised of 10 employees being in direct and constant contact with one or more colleague with a disability. They worked together, frequently working at neighboring desks, and their daily collaboration was an essential part of the department's function.

The free association method of De Rosa enabled identifying a certain number or words and expressions attached to an inductive term. We asked both groups to respond spontaneously to the following question: "What four words come to mind when you hear the expression 'disability at work'?" For each word pronounced we asked to specify whether, for them, it had a positive or a negative connotation ( + or -$)$. We then asked them to rank their replies in order of importance (from 1 to 4 ). We also noted the frequency $(F)$, that is, the number of times the words or expressions were articulated by the members of the groups. The first results show that, in Group A, words with a positive connotation which appeared most frequently were "adaptation" $(F=10)$, "awareness" (8), and "stigma" (5). The words with a negative connotation were "denial" (6), "embarrassment" (5), and "lack of training" (5). From group B we noted that more words with a positive connotation appeared. We heard "no difference" $(F=5)$, but also "ignorance," "openness of mind," "no hindrance," and "integration." Among the words with a negative connotation, we heard "fear" $(F=4)$ and the words "denial" and "embarrassment" $(F=3)$. To find the central core of views $(C C)$, we then calculated the ratio between the average level $(\mathrm{L})$ and the frequency $(F)$. The closer this number is to 0 , the closer the corresponding word or expression is supposed to be to the central core of the views. The results are displayed in the table (Appendix C). The ratio 
between the average level of importance (L) and the frequency of appearance $(F)$ shows that the expressions closest to the central core $(<1)$ are only slightly different between the two groups. In Group A, the central core of representations comprised words and expression with positive connotations such as "awareness" $(0.25)$, "adaptation" $(0.26)$, and "no difference" (0.55), and those with a negative connotation such as "lack of training" $(0.4)$ and "denial" (0.52). In Group B, we note, as before, a greater predominance of words with a positive connotation such as "ignorance" $(0.33)$, "no difference" $(0.4)$, "integration" $(0.55)$, and "open-mindedness" $(0.66)$. No word with a negative connotation appears in the central core with a result below 0.75 .

In summary, the results from analyzing the views reveal an overrepresentation of words and expressions with positive connotations from the group in direct and regular contact with their colleagues with disabilities. Although the differences between the two groups are not fundamental, they nevertheless do tend to affirm positive progress in how employees regard their colleagues with disabilities when they are in a constant and close relationship.

The emergence of these two categories of views with different connotations is moreover confirmed by an analysis of informal exchanges we had during our work in immersion. The selected extracts from interviews show that, in Group A, attitudes oscillate between discomfort and embarrassed silence, with disability being minimized, poorly regarded, and sometimes even denied (See Figure 1). Those interviewed expressed a lack of training, a certain level of fear, embarrassment, and even a certain indifference concerning issues relating to disability. Those belonging to Group B tended to show a more compassionate attitude toward their disabled work colleagues. They showed themselves to be sensitive to the situation of their colleagues with disabilities, developed a real empathy for them, and claimed that their view of them had changed. 


\begin{tabular}{|c|c|}
\hline $\begin{array}{l}\text { Group A } \\
\text { Those with an indi- } \\
\text { rect and irregular } \\
\text { contact with their } \\
\text { colleagues with } \\
\text { disabilities and for } \\
\text { whom their view of } \\
\text { them had changed } \\
\text { little }\end{array}$ & $\begin{array}{l}\text { (2) "It's a subject that we never raise (...) I don't know if this is through embar- } \\
\text { rassment or simply out of concern for others, but we never speak about it." } \\
\text { (4) "I become embarrassed because I don't really know how to react or } \\
\text { behave with someone who is disabled." } \\
\text { (7) "Disability frequently invokes inferiority for me." } \\
\text { (16) "Disability is frequently treated with indifference as long as one does not } \\
\text { come face to face with the problem." } \\
\text { (17) "Disability always seems to engender some sort of fear when one has not } \\
\text { really been confronted by it." } \\
\text { (17) Talking about disability at work is complicated - we need results and } \\
\text { there s money at stake." } \\
\text { (18) "The subject of disability remains a bit vague. We don't really want to } \\
\text { discuss it." }\end{array}$ \\
\hline $\begin{array}{c}\text { Group B } \\
\text { Those with a direct } \\
\text { and } \\
\text { regular contact } \\
\text { with their disabled } \\
\text { colleagues and for } \\
\text { whom their view of } \\
\text { them had changed as } \\
\text { interactions increased }\end{array}$ & $\begin{array}{l}\text { (6) "What upsets me is to see them in that state, to see how it takes over their } \\
\text { lives." } \\
\text { (8) "He comes for three and half hours every morning and it does him good, } \\
\text { and us also. It's give and take, he needs us and we need him. I would say that } \\
\text { there is a sort of paternal feeling that has been established to keep this con- } \\
\text { tact with our disabled colleague." } \\
\text { (9) "My view has become more and more compassionate - he has changed } \\
\text { and will continue to adapt as his disease evolves." } \\
\text { (10) "With our colleague we realize that we now have a totally different } \\
\text { appreciation of disability." } \\
\text { (12) "Often, I have to go on site to do something instead of him and that } \\
\text { is, in a way, a waste of time. But we adapt to his disability and I prefer to } \\
\text { spend a bit of my time rather than see him suffer and think that he cannot do } \\
\text { anything." } \\
\text { (14) "I think we are a plus for him because we can re-motivate and encour- } \\
\text { age him, but also don't let him overextend himself and we shield him from his } \\
\text { disease." }\end{array}$ \\
\hline
\end{tabular}

Figure 1. Extracts from informal exchanges with disabled and nondisabled employees.

Study suggests that those employees who work regularly with people with disabilities develop views that are overall more positive toward them. For them, there is no difficulty in working with disabled colleagues at their place of work. In this, our results mirror those of the national surveys carried out in recent years and which we discussed in the first part. Although some employees could feel embarrassment in working with people with disabilities, their misgivings seem to disappear with time. Most of the people with whom we discussed the issue claim, with a mixture of admiration and empathy, that they understand much better the everyday problems with which their differently abled colleagues are faced.

\section{Discussion}

Most of our interviewees claimed to be very open to the problems of disability, but there were also many who lamented the lack of information and preparation concerning the arrival of a colleague with a disability (it should be noted, however, that according to Article 9 of the Civil Code on the right to privacy, the disabled person has the right to confidentiality. Therefore, the company cannot make public the disability of its employees.). The following extracts from our interviews bear witness to this: 
There is no communication [...] we find out about the disability when the new hire arrives or when our colleagues have become aware of the situation.

If there was more communication in the branch office about disability, the situation would be better both for the person concerned and for the teams working in the field.

In the office we see loads of notices about safety, but very few about disability.

When a new hire arrives with an invisible disability nothing is mentioned by the management, and colleagues only discover several months later the fact that the latest arrival has a disability.

It should be noted that this company is making great strides in improving its policy toward disability. Taking advantage of an agreement signed with the AGEFIPH, relevant flyers are distributed and events are organized. To encourage the integration of workers with disabilities, the company has created a national disability project-P.H.A.R.E. (Disabled Staff: Prepare, Reclassify, Use - with the French word "Phare" meaning a lighthouse or beacon - so the acronym reflects the "guiding" nature of the project), designed to improve the welcome, integration, and job protection for employees with disabilities. As one interviewee confided, this project "indicates that there is relevant documentation to guide us and helps us to adapt our working conditions for our disabled colleagues." It offers training modules for managers and employees where, thanks to real-live experience, "employees can take on board," writes Hingant (2017:77), "that lumbago, depression, diabetes, claustrophobia, or allergies can represent a disability and be considered as disabling afflictions." The national project organizes the annual "Handy" awards. As Barnes et al. (1999) also state, disability as a social model can only evolve if disabled workers play a leading role. Here, the trophies honor its most deserving disabled workers. "We go around the various engineering sites and offices throughout the country," explains one of the organizers, "to obtain first-hand positive feedback on workers with disabilities. These are the only people who are really able to change the attitude of able-bodied employees towards those with disabilities at work." The company is also very active in the sporting arena, and every two years organizes a sports rally for the staff. Teams comprise both able-bodied people and those with disabilities and their colleagues are encouraged to watch the event on giant screens. "There is a real team spirit," relates one of our interviewees, "which enables us to showcase workers with disabilities to others." Thomas,,$\underline{3}$ a top disabled athlete, is a case in point. His participation in the Paralympic Games in Sochi was shown live on giant screens, so that his colleagues could watch his performances. The company has recently created an internal network of some 20 "Disability" ambassadors whose company-wide mission is to highlight positive experiences in terms of integration and employment of people with disabilities. It is worth noting that the company received the 2012 "Diversity" label, further emphasizing the company's commitment to equal opportunity and support for diversity. This recognition has also reinforced the company's positioning as a socially responsible organization.

Thus, implementing a determined internal policy of communication and awareness is revealed as an indispensable building block for a company to remove the barriers to an effective integration of workers with disabilities. As we have tried to show throughout this article, the presence of people with disabilities in the professional world is not something that is easily accepted. Yes, it provokes kindness, even compassion, but also embarrassment and apprehension. To overcome such obstacles, the roles of inter-personal relations and a veritable internal communication and awareness policy are determinant. 


\section{Conclusion}

With regard to intellectual disability, Esnard (1998) observes that social behavior is led by representations, which have an impact on the integration of those concerned. Our study provides some interesting perspectives. It shows that disability at work is incomparably better understood by their able-bodied colleagues when the latter create close and regular daily relationships with their disabled counterparts. All opportunities for creating awareness of disability at work are also extremely pertinent. Although the term disability was poorly understood among the general public several years ago, studies show that attitudes have changed considerably since. The employment rate for physically disabled persons is certainly still insufficient and far from the legally imposed quotas, but our article endeavors to illustrate that real advances have been made. The examples given here are evidence that it is possible to reconcile physical disability and a professional career. The employees that we met were aware that their representations of disability changed through contact with disabled colleagues. Our results show that they feel more related to the issue and that their perception is more positive overall. Interactions between employees demonstrate their ability to change social representations of disability. Certainly, they contribute to the social construction of disability.

However, our analysis includes clear limitations. The free association method presents semantic biases. The analysis of interview content cannot fully reproduce the interlocutors' thoughts and types of self-censorship are always possible. Thus, it would seem appropriate to have a better analysis of how, in the context of an organizational inductive element, interpersonal relations may contribute to optimizing acceptance and inclusion of disability in a company or organization. In-depth studies, in the form of real-life personal accounts will be, in this context, particularly useful.

\section{Appendix A}

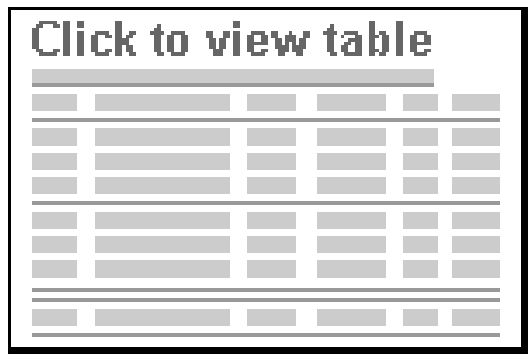

Table A1. List of People Surveyed in the Presurvey (22).

Table A1. List of People Surveyed in the Presurvey (22). 
Table AI. List of People Surveyed in the Presurvey (22).

\begin{tabular}{ll}
\hline Role & \multicolumn{1}{c}{ Company } \\
\hline National head of the disability mission & Mutualité sociale agricole (MSA) \\
Head of the disability and integration project & Disney \\
Department of Major accounts & AGEFIPH \\
Physiotherapist (disabled employee) & Center de rééducation Martel \\
Head of the disability mission (disabled employee) & Clarins \\
Physiotherapist (disabled employee) & Fondation Saint Marie \\
Head of socio-professional supervision for elite athletes & Fédération Française handisport (French \\
& Federation for disability sports) \\
HR and disability mission & Havas \\
Head of the national disability mission & GDF SUEZ Cofely Ineo \\
Quality technician (disabled employee) & Elissor \\
Sports consultant (disabled employee) & Handiamo! \\
PhD in economics and management & Paris town hall \\
Head of the disability mission & Assystem France and E\&OS \\
Vice president for Social action, health and social & Région île-de-France \\
education, Health and Disability & \\
Head of disability mission & BUT \\
University lecturer, PhD in management science & École de management de Nantes \\
Head of training & TH Conseil \\
Inter-regional head of the île-de-France disability mission & FIPHFP \\
Head of the disability mission & RATP \\
Office of career support & Social ministries \\
Deputy director & Diversidées \\
Co-founder CEO & Handiamo! \\
\hline
\end{tabular}

Note. To conduct our presurvey, we spoke with 22 professionals working in the field of disability, including five disabled persons. The responsibilities that they work with allowed us to collect information that helped us to understand the subject of our study.

\section{$\underline{\text { View larger version }}$}

\section{Appendix B}

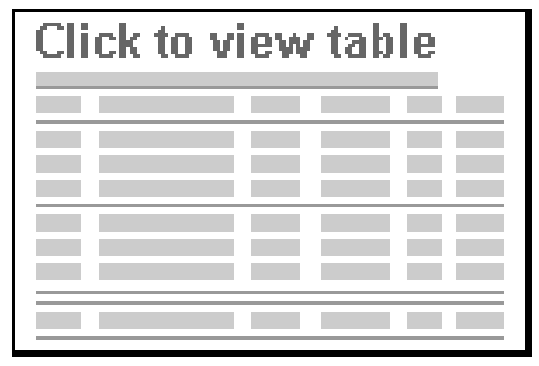

Table B1. Sex and Roles of People Surveyed in Line With the Free Association Method.

Group A: People with Indirect and Irregular Contact with a Disabled Colleague (20 Employees).

Table B1. Sex and Roles of People Surveyed in Line With the Free Association Method.

Group A: People with Indirect and Irregular Contact with a Disabled Colleague (20 Employees). 
Table BI. Sex and Roles of People Surveyed in Line With the Free Association Method. Group A: People with Indirect and Irregular Contact with a Disabled Colleague (20 Employees).

\begin{tabular}{ll}
\hline Sex & \multicolumn{1}{c}{ Role } \\
\hline M & Design office technician \\
M & Business manager \\
M & Cryptographer (pricing study) \\
M & Construction site manager \\
F & Deputy head of maintenance and service \\
M & Office assistant \\
$F$ & Deputy branch manager \\
$F$ & Payroll administrator \\
$M$ & Office assistant \\
$F$ & Deputy branch manager \\
M & HR assistant \\
M & Head of shop security \\
$F$ & Maintenance technician \\
$F$ & Head of maintenance contract \\
$F$ & Project assistant technician \\
$F$ & Reception assistant \\
M & Office manager \\
F & HR manager \\
M & Design office manager \\
\hline
\end{tabular}

View larger version

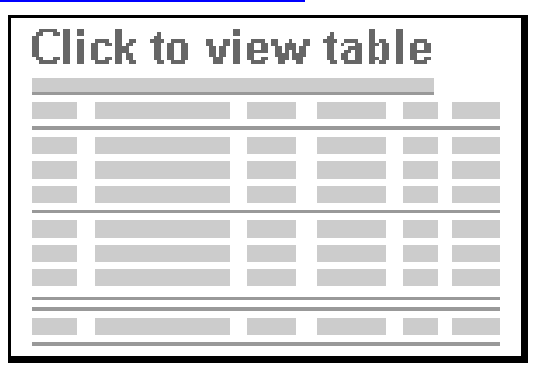

Group B: People with Direct and Regular Contact with a Disabled Colleague (10 Employees).

Group B: People with Direct and Regular Contact with a Disabled Colleague (10 Employees).

Group B: People with Direct and Regular Contact with a Disabled Colleague (10 Employees).

$M$

$M$

$M$

$M$

$M$

$F$

F

$M$

$M$

$M$
Research technician

Research technician

Research technician

Trade unionist

Research technician

Research technician

Project manager

Office manager

Office manager

Project manager

\section{$\underline{\text { View larger version }}$}




\section{Appendix C}

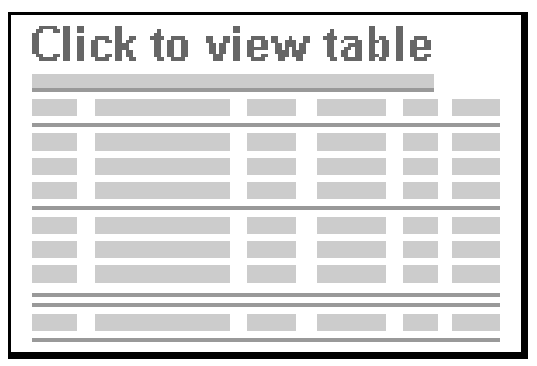

Table C1. Correlation between the Level of Importance and the Frequency of Appearance Using the Free Association Method.

Group A: People with Indirect and Irregular Contact with a Colleague with a Disability (20 Respondents).

Table C1. Correlation between the Level of Importance and the Frequency of Appearance Using the Free Association Method.

Group A: People with Indirect and Irregular Contact with a Colleague with a Disability (20 Respondents).

Table Cl. Correlation between the Level of Importance and the Frequency of Aopearance Using the Free Asiociation Method. Group Ac People wich lndirect and Irregular Contact with a Colleague with a Dinatilicy (20 Respondenes).

\begin{tabular}{|c|c|c|c|c|c|c|c|c|c|c|c|c|c|c|c|c|c|c|c|c|c|c|c|c|}
\hline \multicolumn{25}{|l|}{ Words } \\
\hline Respondents & 1 & 2 & 3 & 4 & 7 & 16 & 17 & 18 & 19 & 20 & 21 & 22 & 23 & 24 & 25 & 26 & 27 & 28 & 29 & 30 & $F$ & t* & $\mathrm{A}+-$ & CC (UF) \\
\hline lynorance & 1 & & I & & & & & 4 & & & & & & & & 4 & & & & & 4 & 2.5 & + & 0.62 \\
\hline Fear & 2 & & & & & & & & & & & & & & & & & & & & I & 2 & - & 2 \\
\hline Denial & 3 & & & & & & & & 3 & & & & & 3 & 2 & & & 4 & 4 & & 6 & 3.16 & - & 0.52 \\
\hline Lateness & 4 & & & & & & & & & & & & & & 3 & & & & & & 2 & 3.5 & + & 1.75 \\
\hline Embarrassmene & & 1 & & 4 & & & & & & 3 & 4 & & & & & & 3 & & & & s & 3 & $=$ & 0.6 \\
\hline Mockery & & 2 & & & & & & 3 & & 4 & & & & & & & & & & & 3 & 3 & - & 1 \\
\hline Awareness & & 3 & & 2 & & 2 & & & & 2 & & 1 & & 1 & & & & 2 & & 3 & 8 & 2 & + & 0.25 \\
\hline No difference & & 4 & & 1 & & & & I & & & & & & & & & & & & & 3 & 2 & + & 0.65 \\
\hline Problem & & & & & & 1 & & & & & & & & & & & & & & & 1 & 1 & - & 1 \\
\hline Difficult to actept & & & 3 & 3 & & & & & & & & & & & & & & & & & 2 & 3 & - & 1.5 \\
\hline Stigna & & & 4 & & & & & & 4 & & & & & & & & 4 & 3 & & 1 & 5 & 3.2 & + & 0.64 \\
\hline Tolerance & & & & & 2 & & & & & & 2 & 4 & & & & & & & & & 3 & 2.66 & + & 0.88 \\
\hline Admiration & & & & & & & & & & & & & & & & & & & & & 0 & 0 & + & 0 \\
\hline Openness of mind & & & & & & & $\mathbf{3}$ & & & & & & & & & & & & & & 2 & is & + & 0.75 \\
\hline Adaptation & & & & & 1 & 4 & & & 2 & & 1 & 3 & 4 & 4 & 4 & & & & 1 & 2 & 10 & 2.6 & + & 0.26 \\
\hline Tabco wbject & & & & & & & & & & & & & 1 & & & & & & & & 1 & 1 & - & 1 \\
\hline No difference & & & & & 3 & & & & $\mathbf{I}$ & & & & & & & & 1 & & & & 3 & 1.66 & + & 0.55 \\
\hline Non-itsue & & & & & 4 & & & & & & & & & & & & 2 & & & & 2 & 3 & + & 1.5 \\
\hline Opposition to change & & & & & & & & & & & & & & & & & & & & & 0 & 0 & $=$ & 0 \\
\hline An asset for the company & & & & & & & 1 & & & & & & & & & 3 & & & & 4 & 3 & 2.66 & + & 0.83 \\
\hline No hindrance & & & & & & & & & & & & & 3 & & & 1 & & & & & 2 & 2 & + & 1 \\
\hline Integration & & & & & & & & & & & & & 2 & & & 2 & & & & & 2 & 2 & + & I \\
\hline Fitting out the workstation & & & & & & & & & & & & & & & & & & 1 & & & 1 & 1 & - & 1 \\
\hline Wheelchair & & & & & & & & 2 & & & & & & & & & & & & & 1 & 2 & - & 2 \\
\hline Lack of training & & & & & & 3 & & & & 1 & 3 & 2 & & & 1 & & & & & & 5 & 2 & - & 0.4 \\
\hline Bad image & & & & & & & 4 & & & & & & & & & & & & 2 & & 2 & 3 & - & 1.5 \\
\hline Safety issues & & & & & & & 3 & & & & & & & & & & & & 3 & & 2 & 3 & $=$ & i.s \\
\hline
\end{tabular}

\section{$\underline{\text { View larger version }}$}

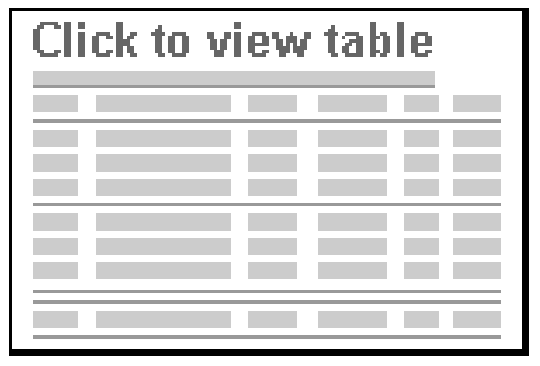

Group B: People with Direct and Regular Contact with a Colleague with a Disability (10 Respondents).

Group B: People with Direct and Regular Contact with a Colleague with a Disability (10 Respondents). 
Group B: People with Direct and Regulur Contact with a Colleagoe with a Disablity (10 Reipendent),

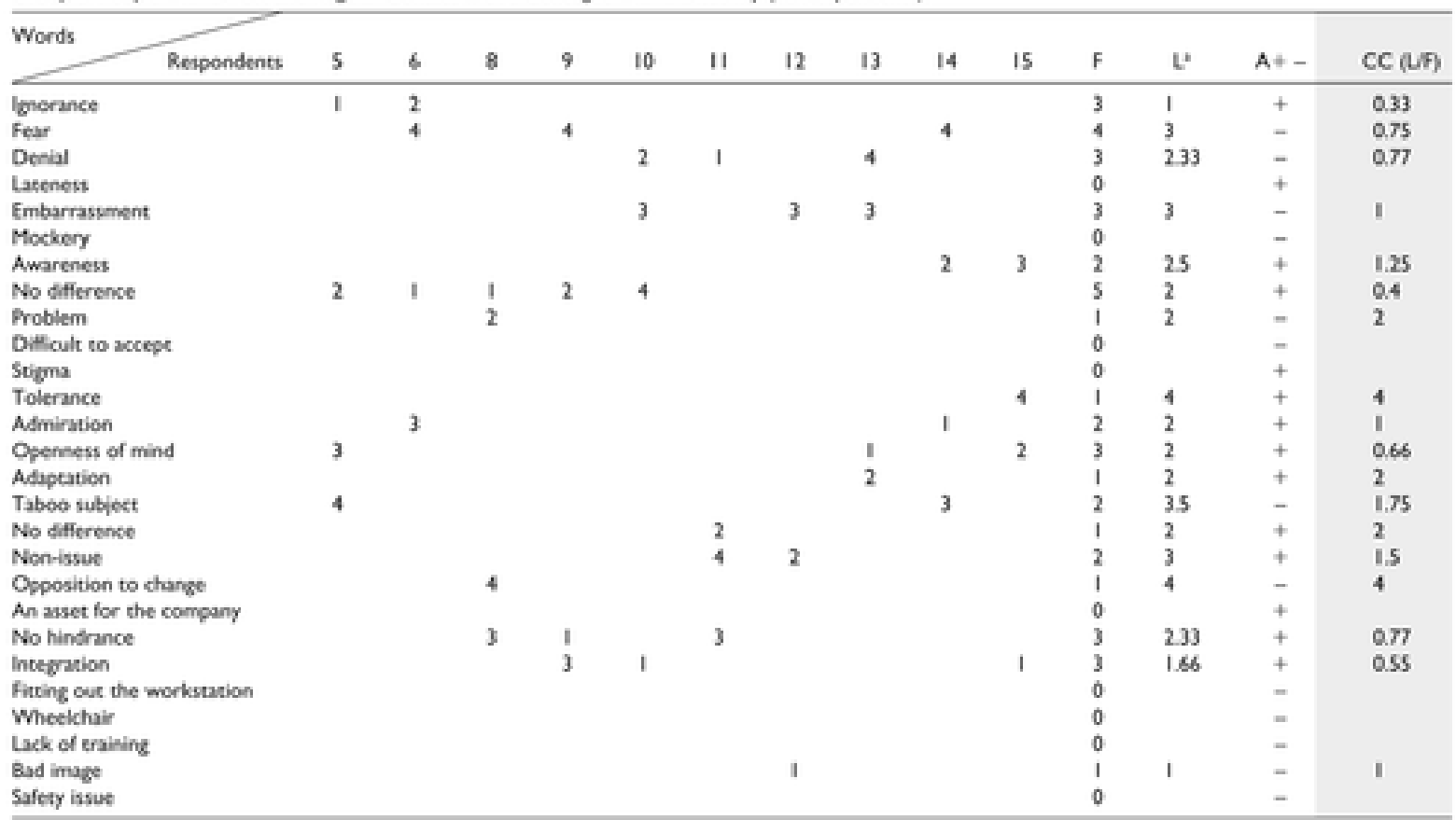

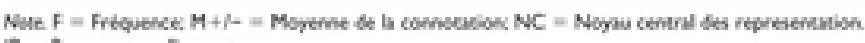

"R. = Rang mopen dimgortano

\section{$\underline{\text { View larger version }}$}

Declaration of Conflicting Interests

The author(s) declared no potential conflicts of interest with respect to the research, authorship, and/or publication of this article.

Funding

The author(s) received no financial support for the research, authorship, and/or publication of this article.

ORCID iD

Bernardeau-Moreau Denis

https://orcid.org/0000-0003-0156-7562

\section{Notes}

1AGEFIPH (French National Association for Managing Funds for the Inclusion of Disabled Persons in the Workplace-Association Nationale pour la Gestion du Fonds pour l'Insertion Professionnelle des Personnes Handicapées) and FIPHFP (Funds for Including Disabled Persons in the Civil Service-Fonds pour l'Insertion des Personnes Handicapées dans la Fonction Publique) aim to promote the inclusion of disabled persons in jobs in private companies, first, and in public companies, second.

2Actions in the symposium "Handicap : de la volonté d'agir au changement du regard handicap" (Disability: from a desire to act to changing views of disability), October 2010, Chamber of commerce and professions, Groupe Mornay. 
3Thomas is visually impaired. He works at the Martel de Janville Rehabilitation Center in Bonneville. In addition, he is an elite athlete and won a medal at the Paralympic Games in Sochi.

\section{References}

Abberley, Paul . 1987. "The Concept of Oppression and the Development of a Social Theory of Disability." Disability, Handicap \& Society 2:5-19.

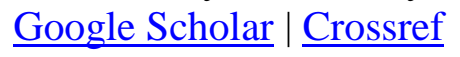

Abric, J. Claude . 1994. Pratiques sociales et représentations [Social practices and representations]. Paris, France: Presses Universitaires de France.

Google Scholar

Abric, J. Claude . 2005. Méthodes d'étude des représentations sociales [Methods for studying social representations]. Paris, France: ERES « Hors collection».

Google Scholar

Auerbacher, Elisabeth . 2007. "Politique, handicap et discriminations." [Politics, disability and discrimination]. Reliance 1(23):100-102.

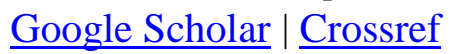

Barbusse, Béatrice . 2002. "Sport et entreprise: des logiques convergentes?” [Sport and business: converging logics?]. L’Année sociologique 52:391-415.

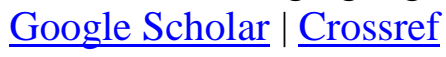

Barbusse, Béatrice . 2009. "Entre sport et entreprise, une attirance réciproque." [Between sport and business, a reciprocal attraction]. L'expansion Management Review 134:10-19.

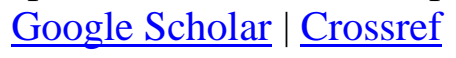

Barel, Yvan, Fremeaux, Sandrine. 2012. "Les attitudes face à la contrainte légale. L'exemple de l'intégration professionnelle des personnes handicapées." [Attitudes towards legal constraint. The example of the professional integration of people with disabilities]. RIMHE 2(2):33-49.

Google Scholar

Barnes, Colin, Mercer, Geoffrey, Shakespeare, Tom. 1999. Exploring Disability: A Sociological Introduction. Cambridge, England: Royaume-Uni Polity Press.

$\underline{\text { Google Scholar }}$

Blanc, Alain . 2006. "Handicap et insertion professionnelle: égalité et démocratie."

[Disability and Inclusion in the Workplace: Equality and Democracy]. Reliance 19:42-49.

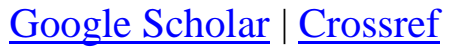

Camberlein, Philippe . 2011. Politiques et dispositifs du handicap en France [Disability policies and systems in France]. Paris, France: Dunod.

Google Scholar 
Compte, Roy . 2008. "De l'exception à la reconnaissance de la personne handicapée en France: Un long et difficile processus d'intégration." [From the exception to the recognition of people with disabilities in France: A long and difficult integration process]. Erès: Empan 2(70):115-22.

Google Scholar

Conrad, Paul, Barker, Kristin K. 2010. “The Social Construction of Illness.” Journal of Health and Social Behavior 51: S67-S79.

$\underline{\text { Google Scholar | SAGE Journals | ISI }}$

Davin, Bérangère, Joutard J, Xavier, Moatti, Paul, Paraponaris, Alain, Verger, Pierre. 2006. "Besoins et insuffisance d'aide humaine aux personnes âgées à domicile: une approche à partir de l'enquête Handicaps, incapacités, dépendance." [Needs and inadequacies of human assistance to older people at home: an approach based on the Disabilities, incapacities, dependency survey]. Sciences Sociales et Santé 24:59-93.

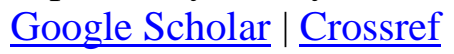

De Foucault, Jean-Baptiste, Piveteau, Denis. 1995. Une société en quête de sens [A society in search of meaning]. Paris, France: Odile Jacob.

Google Scholar

De Rosa, A. Sophie . 2003. Le "réseau d'associations." [The "network of associations]" Pp. 81-118 in Méthode d'étude des représentations socials (2ème édition 2005) [Méthods for studying social representations. (2nd edition 2005)], edited by Abric, J. Claude . Ramonville Saint-Agne, France: Erès.

$\underline{\text { Google Scholar }}$

Esnard, Catherine . 1998. "The social represdentations of mental disability in medico-social professionnals". Européean Journal of Mental Disability, 5(19): 10-23.

Google Scholar

Ferreol, Gilles . 1991. Dictionnaire de sociologie [Dictionary of Sociology]. Paris, France: Armand Colin.

Google Scholar

Gardou, Charles . 1991. Le Regard Interrogé: Handicaps-Handicapés [Handicaps-

Disabilities]. Toulouse, France: Edition ERES.

$\underline{\text { Google Scholar }}$

Guichet, Franck, Kaczmarek, Sylvie. 2016. "Les entreprises face au handicap: Freins et leviers pour agir." [Companies and disability: brakes and levers for action]. Observatoire de la Fondation Malakoff Médéric Handicap [Observatory of the Malakoff Médéric Handicap Foundation]. Retrieved December 11, 2020 (http://www.fondationhandicapmalakoffmederic.org/wp-content/uploads/2016/11/AFNH1605-4908.pdf) $\underline{\text { Google Scholar }}$

Hingant, Marie . 2017. "Le handicap physique au travail: évolutions, vécus et communication 
interne." Le cas des travailleurs sportifs et non sportifs, thèse de doctorat en staps [Physical disability in the workplace: developments, experiences and internal communication. The case of sport and non-sport workers, $\mathrm{PhD}$ thesis in staps]. Université De Paris-est Marne La Vallée [University of Paris-est Marne La Vallée]. Retrieved December 11, 2020 (https://tel.archives-ouvertes.fr/tel-01937276/document) Google Scholar

Kerroumi, Bernard. 2007. "Responsabiliser le management." [Making management accountable]. Pp. 161-67 in Désinsulariser le handicap [Making disability commonplace], edited by Poizat, Daniel, Gardou, Charles. ERES “Connaissances de la diversité. Google Scholar

Le Dantec, Joel . 2004. "Entre travail et handicap.” [Between work and disability]. Empan 55:73-80

\section{$\underline{\text { Google Scholar } \mid \underline{\text { Crossref }}}$}

Le Houerou, Annie . 2014. "Dynamiser l'emploi des personnes handicapées en milieu ordinaire. aménager les postes et accompagner les personnes." [Boosting the employment of people with disabilities in ordinary environments, adapting jobs and supporting people]. Rapport parlementaire remis au 1er Ministre en septembre [Parliamentary report submitted to the Prime Minister in September]. Retrieved December 11, 2020 (https://www.viepublique.fr/sites/default/files/rapport/pdf/144000661.pdf). Google Scholar

Morin, Bernard . 2006. "L'insertion professionnelle des personnes en situation de handicapRéflexion à partir d'une pratique en entreprise." [Professional integration of people with disabilities - Reflection based on a company practice]. Reliance 19:62-66.

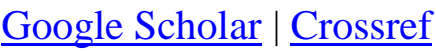

Mormiche, Pierre, Goillot, Catherine. 2003. "Enquête Handicap-Incapacités-Dépendances de 1998-1999.” [Handicap-Incapacity-Dependency Survey 1998-1999]. Société 22.

Google Scholar

Moscovici, Serge . 1982. "The Coming of Social Representations." [The Coming of Social Representations]. in Cognitive approaches the social behaviour [Cognitive approaches the social behaviour], edited byCodol, J. P., Leyens, J. P. The Hague, The Netherlands: Nijhoff. Google Scholar $\mid \underline{\text { Crossref }}$

Moscovici, Serge . 2003. "Des représentations collectives aux représentations sociales: éléments pour une histoire." [From collective representations to social representations: elements for a story]. Pp. 79-103 in Les représentations socials (7ème édition) [in social représentations (7th edition)], edited by Denise, Jodelet . Paris, France: Presses Universitaires de France "Sociologie d'aujourd'hui.

Google Scholar $\mid \underline{\text { Crossref }}$

Point, Serge, Charles-Fontaine, Céline, Berthélemé, Gwanael. 2010. “(Re)considérer le handicap: regards croisés sur les approches en entreprise." [“( $\mathrm{Re})$ considering disability: cross-examination of approaches in the workplace"] Management \& Avenir 38(8):293-305. 


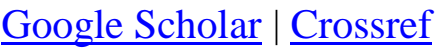

Weber, Max . 1971. Économie et Société [Economy and Society]. Paris, France: Plon tome 2. Google Scholar

Author Biography

Bernardeau-Moreau Denis is professor of sociology at the University of Lille (France). His research focuses on three themes: the sociology of organizations and intervention (professional evolution of associative, sports and leisure organizations), the sociology of volunteering and associations (professionalization and referentials of volunteers' skills), and the sociology of sports and health in companies (relaxation, well-being, fight against vulnerabilities and burnout). He has published about 50 articles and book chapters. Teaching at the University of Lille, he also collaborates with the Universities of Nanterre (France) and Rohtak (India). 